\title{
Police Powers and Article 5 ECHR: Time for a New Approach to the Interpretation of the Right to Liberty
}

\author{
Richard A. Edwards ${ }^{1}$ (D) \\ Published online: 22 July 2020 \\ (c) The Author(s) 2020
}

\begin{abstract}
This paper discusses the approach of British and European Courts to the interpretation and application of the Article 5 ECHR right to liberty when faced with police powers. The paper argues that the long-standing approach of the European Court of Human Rights in Guzzardi v Italy [1980] ECHR 7367/76 is wrong and should be replaced with a new interpretation based on coercion. The paper goes on to argue that a new approach would allow the courts to effectively protect both Convention rights and the rule of law.
\end{abstract}

Keywords ECHR · HRA · Human rights · Legality $\cdot$ Rule of law $\cdot$ Right to liberty · Police powers

\section{Introduction: The Problem}

Legal black holes come in many shapes and forms. Some are created by the executive $^{1}$ while others are fashioned by the legislature. ${ }^{2}$ Both are a danger to the rule of law. Legal black holes 'create a zone in which officials can act unconstrained by the rule of law. ${ }^{3}$ But they are not the most invidious threat to legality. Of greater danger are what Dyzenhaus calls grey holes: black holes lurking behind a façade of legality but in practice denying its substantive protections. Grey holes are especially invidious when their creation is assisted by the judiciary for 'a little bit of legality can be more lethal to the rule of law than none. ${ }^{4}$ But when we examine the approach of the

\footnotetext{
${ }^{1}$ See for example Steyn (2004); $R$ (Abbassi) v Secretary of State for Foreign Affairs [2002] EWCA Civ 1598; $R$ v Secretary of State ex parte Hosenball [1977] 1 WLR 766.

${ }^{2}$ Privative clauses, for example: $R$ (Privacy International) $v$ Investigatory Powers Tribunal [2019] UKSC 22, [2019] 2 WLR 1219.

${ }^{3}$ Dyzenhaus (2006, p 202).

${ }^{4}$ Ibid, p 50. Liversidge v Anderson [1942] AC 506.
}

Richard A. Edwards

r.a.edwards@exeter.ac.uk

1 Exeter Law School, University of Exeter, Exeter, UK 
British judiciary to grey holes we find a troubling paradox. When faced with grey holes in cause célèbres ${ }^{5}$ the courts have been commendably robust. But when presented with cases involving prosaic police powers the courts have been a model of self-denying ordinance. In several cases involving the Convention right to liberty the judiciary has failed to close grey holes by ensuring that they are properly governed by the rule of law. And in one remarkable case, Austin, ${ }^{6}$ the judiciary themselves have created a serious grey hole in the protection of liberty.

The right to liberty and security is enshrined in Article 5 of the European Convention on Human Rights. ${ }^{7}$ Article 5, the European Court of Human Rights ${ }^{8}$ frequently reminds us, is intended to protect individuals from arbitrary ${ }^{9}$ or unjustified ${ }^{10}$ interferences with their right to physical liberty ${ }^{11}$ and security. ${ }^{12}$ The framers of the ECHR had in mind the classical deprivations of liberty such as arrest or the detention of a gaoler, and the text of Article 5 certainly reflects this. ${ }^{13}$ Indeed, many of those involved in drafting the Convention had first-hand experience of police states, and this loomed large in their thinking. ${ }^{14}$ But since 1950 the nature of policing has changed considerably and with it the powers granted by the state to police officers. As Murray details, stop and search powers barely existed in $1950 .{ }^{15}$ Yet today stop and search powers are a ubiquitous, if somewhat controversial, part of modern policing. The historic approach to policing, based on securing prima facie evidence of criminality before acting, has been displaced by a preventative approach based largely on suspicion or risk. Equally, significant are the legislative responses to terrorism which, in short, have significantly augmented police powers. ${ }^{16}$ These when combined with a paramilitary style of policing public order disturbances have moved policing away from its traditional Peelite roots. ${ }^{17}$ Today, in addition to arrest, the citizen can be subject to a wide range of modern police powers that have clear implications for liberty. These powers come in many forms. For instance, notwithstanding powers enacted to deal with terrorism, police officers enjoy powers to stop and search powers, ${ }^{18}$ the power to conduct road traffic

\footnotetext{
${ }^{5}$ A v Secretary of State for the Home Department [2004] UKHL 56, [2005] 2 AC 68.

${ }^{6}$ Austin v Commissioner of Police of the Metropolis [2009] UKHL 5, [2009] 1 AC 564. Herein Austin HL.

7 Herein ECHR. Article 5(1) provides: 'Everyone has the right to liberty and security of person. No one shall be deprived of his liberty save in the following cases and in accordance with a procedure prescribed by law...' The article then lists six grounds on which the right to liberty may be limited by the state. Herein referred to as Article 5.

8 Herein referred to as the European Court.

9 Askoy v Turkey [1996] ECHR 21987/93, [76].

10 McKay v United Kingdom [2006] ECHR 543/03, [30].

11 Engel $v$ The Netherlands [1976] ECHR 5100/71, [58]. Herein Engel.

12 Nikolaishili v Georgia [2009] ECHR 37048/04, [53].

13 Council of Europe (1956).

14 Ibid, pp 4-5.

15 Murray (2018, pp 600-602).

16 See for example Donohue (2007) and Walker (2011).

17 Waddington (1987, p 45), noting the threat that paramilitary style policing poses to liberty.

18 Police and Criminal Evidence Act 1984, s 1.
} 
stops, ${ }^{19}$ the power to stop and check travel documents, ${ }^{20}$ and the common law power to control crowds.

Yet, as will be shown below, the impact of Article 5 on such powers has been surprisingly limited. In several cases dealing with police powers the courts have decided that Article 5 simply does not apply. The leading cases will be examined below. This development has created a legal grey hole, allowing the police to detain and control individuals with little judicial oversight before there is sufficient suspicion to arrest them. ${ }^{21}$ Untroubled by the possibility of Convention scrutiny the police enjoy openended, low visibility, permissive discretionary powers ${ }^{22}$ that are at times used in a discriminatory manner. ${ }^{23}$ Yet we are frequently told that the Convention is a living instrument 'which must be interpreted in light of present day conditions.' ${ }^{24}$ This paper argues that the current approach of the courts to the interpretation of Article 5 fails to take account of 'present day conditions' in this important context, and needs as a consequence to be reconsidered. The problem is illustrated by the case of Roberts, discussed immediately below. ${ }^{25}$ The paper goes on to argue that in situations beyond the paradigm deprivations of liberty, namely custody and arrest, a new test for the deprivation of liberty under Article 5 needs to be adopted. The seeds for change are already present in the European Court's case law. As we shall see these seeds, when combined with lessons from Canadian law, offer a better approach to the interpretation of Article 5.

\section{The Problem Illustrated: R (Roberts) v Commissioner of Police of the Metropolis}

An excellent illustration of the current approach to the interpretation of Article 5 by domestic courts can be seen in the case of Roberts. ${ }^{26}$ In Roberts the applicant had been travelling on a municipal bus when a ticket inspector discovered that she had insufficient funds to cover the cost of her bus journey. An argument developed between the inspector and the applicant, during which she provided false details to the inspector. The police were called when applicant became agitated and was asked to leave the bus in Haringey. At that time, the London Borough of Haringey was blighted by inter-gang rivalry and fighting. Consequently, a police inspector stationed in Haringey had authorised the use of power to stop and search for weapons under section 60 Criminal Justice and Public Order Act 1994 (CJPO). Section 60 CJPO allows a police officer to stop and search, without reasonable suspicion,

\footnotetext{
19 Road Traffic Act 1998, s 6 and ss 163-164.

20 Anti-Social Behaviour, Crime and Policing Act 2014, s 147 and Schedule 8.

21 Murdoch (1993, pp 494-522, p 497).

22 Goldstein (1959-1960).

23 Equality and Human Rights Commission (2012).

24 Tyrer v UK [1978] ECHR 5856/72, [31].

${ }^{25} R$ (Roberts) $v$ The Commissioner of the Metropolitan Police [2012] EWHC 1977 (Admin), [2012] HRLR 746. Herein Roberts HC.

26 Ibid.
} 
anyone for offensive weapons or dangerous instruments when authorized to do so. ${ }^{27}$ It is an offence not to stop. ${ }^{28}$ One of the attending police officers decided to search the applicant using the section 60 CJPO power. The applicant refused to be searched, kept firm hold of her bag and attempted to walk away. At this point the police officer told the applicant she was to be detained and, when she resisted once more, with the assistance of other police officers the applicant was handcuffed and pinned to the ground. The applicant's bag was then searched, and on discovering bank cards in her maiden name and her son's name she was arrested on suspicion of handling stolen goods and taken to Tottenham Police Station. But once the applicant's identity had been established at the police station, she was released without charge. The applicant subsequently brought judicial review proceedings alleging breaches of Articles 5, 8 and 14 of the ECHR. At first instance Moses LJ held that there had been no deprivation of liberty during this process. Article 5 was not engaged. Moreover, had the claimant not resisted the stop and search would have had lasted only a few minutes. In reaching this decision Moses LJ referred not only to the House of Lords decision in Gillan ${ }^{29}$ but also to the more recent judgment of the European Court of Human Rights in Austin. ${ }^{30}$ According to Moses LJ the European Court in Austin had sensibly concluded 'that the police must be afforded a degree of discretion in taking operational decisions and that Article 5 should not be interpreted in such a way as to make it impracticable for the police to fulfill their duties of maintaining order and protecting the public. ${ }^{31}$ The applicant appealed. Before the Court of Appeal Article 5 received only cursory treatment with Maurice Kay LJ concluding that he was 'entirely satisfied that [Article 5] has no application in the present case., 32 There was no appeal to the Supreme Court on the question of whether Article 5 was engaged. ${ }^{33}$ In many ways Roberts is an unremarkable case. Stop and search powers are routinely and extensively used by the police. ${ }^{34}$ In this sense Mrs Roberts' experience was typical. But what is remarkable is the tepid response of English courts when interpreting Article 5. By failing to recognise that the right to liberty and security can apply in such contexts the courts are effectively insulating the initial stages of

\footnotetext{
27 Criminal Justice and Public Order Act 1994, s 60(1) empowers a police inspector to authorize the use of s 60 for a period of twenty-four hours (extendable for another twenty-four hours) where he/she believes that it is either expedient to prevent incidents of serious violence or there may be people carrying dangerous instruments or offensive weapons in any locality in his/her police area without good reason.

28 Criminal Justice and Public Order Act 1994, s 60(8).

${ }^{29} R$ (Gillan) $v$ The Commissioner of Police for the Metropolis [2006] UKHL 12, [2006] 2 AC 307. Herein Gillan HL; Gillan v United Kingdom [2010] ECHR 4158/05, [2010] 50 EHRR 45. Herein Gillan ECHR.

${ }^{30}$ Austin v United Kingdom [2012] ECHR 39692/09, (2012) 55 EHRR 14. Herein Austin ECHR.

31 Roberts $H C$ (n 25 above), [14] quoting in part the judgment of the ECHR in Austin ECHR (ibid), [56].

${ }^{32} R$ (Roberts) $v$ The Commissioner of the Metropolitan Police [2014] EWCA Civ 69, [2014] 1 WLR 3299, [11]-[13].

${ }^{33} R$ (Roberts) $v$ The Commissioner of the Metropolitan Police [2015] UKSC 79, [2016] 1 WLR 210, [14] Baroness Hale DPSC. Herein Roberts SC; Lennon (2016, pp 189-191).

34 Whilst the number of stops has declined over the last ten years, a significant number are still happening. In 2008/09 1.5 million stops and searches were carried out. By 2018/19 383,629 searches were undertaken, resulting in 58,876 arrests (an arrest rate of 15\%). (Home Office 2019).
} 
contact between citizens and the police from judicial scrutiny and thus the rule of law. ${ }^{35}$ Whilst an arrest must naturally be considered a serious intrusion on personal liberty and security, the law should not be indifferent to interferences short of that. Road traffic stops, stops and searches by foot patrols and crowd control measures all interfere with the right to liberty and security.

\section{The Source of the Problem: Guzzardi v Italy}

The tepid response of English courts to Article 5 claims is on one level understandable given the European Court's long-standing approach to the interpretation of this article is itself flawed. At the root of the problem is the test that the European Court has developed for determining whether there has been a deprivation of liberty within the terms of Article 5. The leading authority under Article 5 is Guzzardi v Italy. ${ }^{36}$ In Guzzardi the applicant, a suspected Mafioso, was placed under special supervision by the Italian courts. The special supervision involved an obligation to reside in a $2.5 \mathrm{~km}$ squared corner of an island, Asihara, just off Sardina. The order included a range of measures such as being under a curfew and restrictions on social interaction with the local population. The question before the European Court was whether this supervision regime constituted a deprivation of liberty within Article 5(1) ECHR. The European Court concluded that residence requirement did constitute a deprivation of liberty, with the circumstances resembling in many ways an open prison. ${ }^{37}$ In reaching that conclusion the European Court made a number of seminal observations. The European Court observed that the guarantee contained in Article 5(1) is concerned with 'the physical liberty of the person; its aim is to ensure that no one should be dispossessed of this liberty in an arbitrary fashion ... the paragraph is not concerned with mere restrictions on liberty of movement ... in order to determine whether someone has been "deprived of his liberty" within the meaning of Article 5 the starting point must be his concrete situation and account must be taken of a whole range of criteria such as the type, duration, effects and manner of implementation of the measure in question. ${ }^{38}$ The Court then continued observing that 'the difference between deprivation of and restriction upon liberty is nonetheless merely one of degree or intensity, and not one of nature or substance ... although the process of classification into one or other of these categories sometimes proves to be no easy task in that some borderline cases are a matter of pure opinion, the Court cannot avoid making the selection upon which the applicability or inapplicability of Article 5 depends. ${ }^{39}$

\footnotetext{
${ }^{35}$ Here American law under the Fourth Amendment is much more realistic in its approach. See Terry $v$. Ohio 392 US 1, 10-17 (1968) Warren CJ.

36 [1980] ECHR 7367/76. Herein Guzzardi.

37 Ibid [95].

38 Ibid [92].

39 Ibid [93]. Emphasis added.
} 
There are number of difficulties with the Guzzardi test. To begin with the dividing line between deprivations of liberty and restrictions on liberty is by no means evident. ${ }^{40}$ Furthermore, the provides "neither bright-line rule nor anything that begins to approximate to a clear definition. ${ }^{41}$ Any underlying principle of approach 'is difficult to extract from the decisions and judgments. ${ }^{42}$ Although the Guzzardi test depends on a number of objective criteria it also makes explicit provision for a large element of subjective judgment. This may have attractions from the judicial perspective, granting a broad discretion to determine cases. However, from the perspective of legal certainty-one of the key principles of Article 5-this is decidedly unsatisfactory. Indeed, deciding when a deprivation has occurred is a classic example of Sorites' paradox. When and where does a detention cease to be a restriction and become a deprivation? There is no clear answer, and no governing principles to be found in the jurisprudence. Consequently, the boundary between restriction and deprivation has been rightly described as erratic. ${ }^{43}$ Thus, for example, in Austin the European Court struggled to determine when a restriction on freedom of movement turned into a deprivation of liberty. ${ }^{44}$ It was precisely this problem that exercised Lord Hoffmann in $J J,{ }^{45}$ and led him to conclude that Article 5 ought to be interpreted domestically as applying only to classical or paradigm restrictions on physical liberty such as confinement: 'in order to preserve the key distinction between the unqualified right to liberty and the qualified rights of freedom of movement, communication, association and so forth, it is essential not to give an over-expansive interpretation to the concept of deprivation of liberty. ${ }^{, 46}$ Yet while that might provide a clean solution to the interpretative difficulties of Article 5 it restricts the application of an important guarantee to situations that hardly comports with either the text of the Article or indeed the injunction to read constitutional guarantees in a generous and purposive manner. ${ }^{47}$ Furthermore, Article 5 is shot through with the concept of legality. Limiting its initial application crucially prevents from the outset any effective attempt to properly regulate coercive powers in an increasingly important area. For while modern police powers have developed apace since 1950, neither the text of Article 5 nor indeed the Guzzardi test have been reformulated to match. ${ }^{48}$ Finally, the difficulties in this area are not helped by the inconsistent approach of the European Court to Article 5. Doubtless because of the inherent difficulties of the Guzzardi test the European Court has at times shied away from articulating a more robust and coherent interpretation in appropriate cases. For example, in Stefanov $v$ Bulgaria $^{49}$ the applicant had attended a police station for five hours so that he could

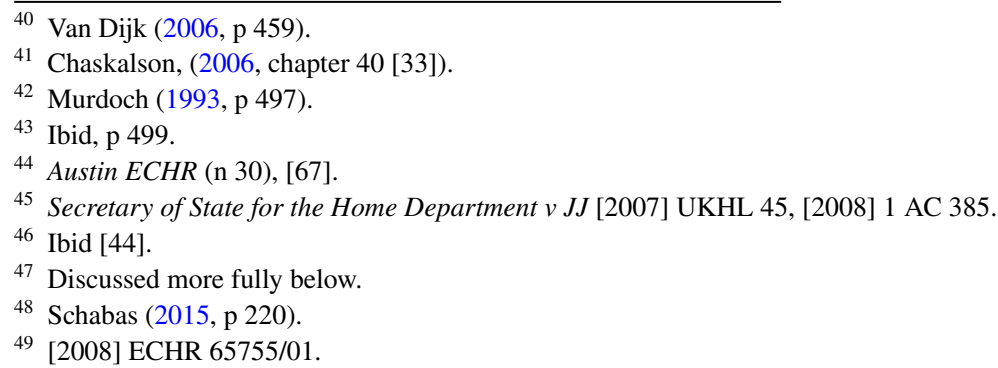


be interviewed as a witness to a criminal investigation. The applicant was kept waiting and told that he was not free to leave. ${ }^{50}$ Before the European Court the applicant contended, amongst other things, that his detention was an unjustified interference with his Article 5 right. In determining that it was not, the European Court unhelpfully assumed, without demonstrating, that the applicant's liberty interests protected by Article 5(1) had been infringed. Remarkably, the court cited many of the earlier contradictory decisions of the Commission and concluded that 'the Court does not need to resolve [this contradiction] in the present case, as even assuming that the applicant was deprived of his liberty, and that Article 5 was thus applicable, it is satisfied that this deprivation of liberty was justified under paragraph 1(b) of this provision. ${ }^{51}$ This is unfortunate because such cases offer the Court a means of clarifying an area of the law badly in need of it.

\section{The Domestic Interpretation of Article 5}

The problem is thus not one that domestic courts are solely responsible for. But they have hardly improved matters. Domestically, as Roberts revealed, the Guzzardi interpretation has been supplemented by a de minimis principle. Domestic courts have restricted the application of Article 5 by holding that the deprivation is trivial and thus falls outside the scope of the guarantee. Thus, in Gillan the use of stop and search powers under the Terrorism Act was held to fall outside the scope of Article 5. ${ }^{52}$ According to Lord Bingham when subject to a stop and search a person was simply 'kept from proceeding or kept waiting. ${ }^{53}$ Whereas in Austin the use of such powers was transitory. ${ }^{54}$ Similarly, in Roberts Moses LJ stressed that had the applicant been cooperative then she would have only been delayed for a matter of a few minutes. Article 5 should not apply to such transitory restrictions on liberty. Thus, the problem of how short-term detention should be regulated by Article 5 has been solved by classifying it as largely inconsequential, unless physical restraint is employed. But this conclusion was unreasoned. In fact, in many of these cases the judges appear to be reasoning intuitively about the experiences of those subject to police powers. ${ }^{55}$ But crucially these experiences are not uniform, and for the members of some communities far from pleasant. ${ }^{56}$

Another excellent illustration of the de minimis approach to Article 5 can be found in Beghal $v$ DPP. ${ }^{57}$ In Beghal the Supreme Court was asked to consider,

\footnotetext{
50 Ibid [71].

51 Ibid [71].

52 Terrorism Act 2000, ss 44-45.

53 Gillan HL (n 29), [25].

54 Austin HL (n 6), [17] Lord Hope.

55 Judgements under the American Fourth amendment dealing with police stops display the same reasoning. See Nadler (2002, pp 163-166).

56 Discussed further below.

57 [2015] UKSC 49, [2016] AC 88. Herein Beghal SC; For an excellent discussion of the decision in Beghal and Roberts see Ip (2017).
} 
amongst other things, the compatibility with Article 5 of powers contained in section 53(1) and Schedule 7 of the Terrorism Act 2000. In the earlier case of $R v G u l^{58}$ the Supreme Court had noted with concern the implications for liberty of the broad statutory definition of terrorism Parliament had adopted in the Terrorism Act ${ }^{59}$ when combined with the wide and intrusive powers which peppered the Act. Lords Neuberger and Judge noted, all be it obiter, that the form of detention contemplated by Schedule 7 presented 'the possibility of serious invasions of personal liberty. ${ }^{\text {, }}$ Beghal was returning from a visit to Paris, where her husband had been detained in connection with suspected terrorist offenses, when she was stopped and questioned under Schedule 7. The powers contained in Schedule 7 granted nominated officers at ports and borders a suspicion-less power to stop, question and detain anyone who appears to be connected terrorist offences for up to six hours. During any such detention officers were free to access, search, seize, copy and retain all the information on the detainee's personal electronic devices such as mobile phones, laptops and tablets. Officers could also during a Schedule 7 detention take and retain DNA samples and fingerprints without consent. Naturally, the Schedule also imposed criminal liability for anyone stopped to willfully fail to comply with the obligations imposed by Schedule $7 . .^{61}$ In Beghal the appellant was not formally arrested ${ }^{62}$ but she was detained at the airport for an hour and three quarters while she was interrogated. Beghal contended that this use of Schedule 7 powers was incompatible with Article 5. The Divisional Court concluded that although Article 5 was engaged, the interference was justified. ${ }^{63}$ Beghal unsuccessfully appealed to the Supreme Court. In dismissing Beghal's appeal the Supreme Court made a number of important observations for the application of Article 5.

In the Supreme Court Lord Hughes concluded that Article 5 was only 'barely' engaged. In fact, his Lordship was unconvinced that Article 5 was engaged, and only proceeded on that basis because the Crown had conceded the point below. ${ }^{64}$ Indeed, had the Crown not accepted the contention that Article 5 applied, it is unlikely the Supreme Court would have examined the application of this Article at all. To put it another way, it is not clear when Article 5 should become engaged as Lord Hughes admitted: 'The appellant was prevented from moving on from the airport for about an hour and three quarters ... whether that period was sufficient to constitute a deprivation of liberty for the purposes of article 5 is a question to which the answer is not clear. ${ }^{95}$ His Lordship then went on to observe that in general preventing a person being questioned leaving during the interrogation would only represent a restriction on movement rather than a deprivation of liberty. However, this is unrealistic. For example, an individual detained under Schedule 7 is in a different to position

\footnotetext{
58 [2013] UKSC 64, [2014] AC 126. Herein Gul.

59 Terrorism Act 2000, s 1.

${ }^{60} \mathrm{Gul}$ (n 58), [63]-[64].

61 Terrorism Act 2000, schedule 7 paragraph 18.

62 Begal SC (n 57), [12].

63 [2014] QB 607.

64 Beghal SC (n 57), [53].

65 Ibid, [53].
} 
to an individual subject to an exclusion order under section 35 of the Anti-Social Behavior, Crime and Policing Act 2014. Where a police officer issues an exclusion order the individual subject to the order may not enter a specified geographical area, but they are free to move elsewhere. ${ }^{66}$ This, arguably, is a restriction on the common law right to freedom of movement. ${ }^{67}$ Whereas an individual subject to the provisions of Schedule 7 cannot move off at all. In fact it is an offence to do so. Be that as it may, Lord Hughes then went on to conclude that if, in practice, there was a deprivation of liberty that this would be justified. ${ }^{68}$ However, once it was accepted that Article 5 was applicable the majority concluded that any interference was justified as being necessary for the completion of the process. ${ }^{69}$ In this conclusion the Supreme Court found support in the decision of the European Court in Gahramanov where the court concluded that ordinary border checks would not engage Article 5 if they do "not exceed the time strictly necessary to comply with relevant formalities. ${ }^{70}$ With respect to ordinary border checks this must be right. But crucially Gahramanov was not concerned with interrogation and detention under counter-terrorism legislation at a border crossing. ${ }^{71}$ But there is a more fundamental problem with the majority's reasoning. Unhelpfully the majority simply concluded that the limitation was justified. There was no demonstration of the limitation's necessity. Perhaps it is inevitable that where a court concludes that a right 'barely applies' any subsequently limitation analysis will be less rigorous, and any interference will be more readily upheld. But this is not what the Convention demands. Once it is accepted that a right has been limited the onus of demonstrating that the interference is necessary falls to the Crown. The justification for the impugned limit must be demonstrably made out, after all these are fundamental Convention rights and freedoms. And crucially the limitations analysis is 'an unavoidably normative inquiry, requiring the courts to take into account both the nature of the infringed right and the specific values and principles upon which the state seeks to justify the infringement. ${ }^{, 72}$ In dissent Lord Kerr took a different approach, undertaking a limitations analysis. ${ }^{73}$ Examining the power to stop, detain, search and question Lord Kerr concluded that there was no evidence that a suspicion-less power was necessary. Indeed, no justification had been provided to that end. In fact, with respect to powers of detention it was

\footnotetext{
66 Anti-Social Behavior, Crime and Policing Act 2014, s 35(1) provides: 'a constable in uniform may direct a person who is in a public place in the locality specified in the authorisationto leave the locality (or part of the locality), and not to return to the locality (or part of the locality) for the period specified in the direction ("the exclusion period").'

${ }^{67} R$ v Secretary of State for the Home Department, ex parte McQuillan [1995] 4 All ER 400, 421-422 Sedley J.

${ }^{68}$ Beghal SC (n 57), [54]. Unfortunately, this conclusion was asserted rather than demonstrated.

69 Ibid [56].

70 Gahramanov v Azerbaijan [2013] ECHR 26291/06, [41].

71 As Lord Steyn once observed 'in law context is everything.' $R$ (Daly) $v$ Secretary of State for the Home Department [2001] UKHL 26, [2001] 2 AC 532, [28].

72 RJR-MacDonald Inc v Canada (Attorney General) [1995] 3 SCR 199, [62] La Forest J.

73 Beghal SC (n 57), [119]-[128].
} 
clear that the measure went beyond what was necessary. ${ }^{74} \mathrm{~A}$ subsequent successful application to the European Court was considered, like Gillan before, under Article 8 ECHR without the court touching upon issues around the application of Article 5. While this accords with the European Court's long-standing practice it nonetheless has the unfortunate effect of diverting attention away from the interpretation of a right that is arguably much more significant in the context of police powers.

These restricted approaches to the interpretation of Article 5 have been further eviscerated by the questionable judgments of both the House of Lords and the European Court in Austin. Austin began with an application for judicial review brought by four people detained by the police in Oxford Street, London during the 2001 May Day demonstrations. Three of the four applicants had no connection with the demonstrations and simply had the misfortune to be in the street when the police cordoned it off. However, all the applicants were told that they were not free to leave and would be arrested if they attempted to do so. The applicants spent the next six to seven hours detained, or 'kettled' as it has become known, in the street awaiting their release. The applicants were unable to leave for any reason. Yet remarkably both the House of Lords and the European Court held that this detention did not involve a deprivation of liberty within the terms of Article 5. In essence, the House of Lords concluded that crowd control measures would not infringe the Article 5 rights of individual members of the crowd. ${ }^{75}$ In the House of Lords Lord Hope gave the leading opinion. In contrast to the previous interpretative approach to Article 5 where the purpose of the deprivation was considered in the context of deciding whether it was justified, ${ }^{76}$ Lord Hope concluded that purpose could be used in determining whether there was a deprivation of liberty. ${ }^{77}$ Similarly, Lord Neuberger concluded that as this was not a paradigm case of detention, the intention of the police was clearly important in determining whether Article 5 applied. ${ }^{78}$ This conclusion is now open to question, for as the Grand Chamber noted shortly before it confirmed the decision of the House of Lords in Austin, 'the purpose of measures by the authorities depriving applicants of their liberty no longer appears decisive for the Court's assessment of whether there has in fact been a deprivation of liberty. ${ }^{79}$ Furthermore, Lord Hope continued, although there was no indication in either the text of Article 5 or the jurisprudence, there were nonetheless 'sufficient indications elsewhere in the court's case law that the question of balance is inherent in the concepts that are enshrined in the Convention and that they have a part to play when consideration is being given to the scope of the first rank of fundamental rights. ${ }^{80}$ This, as some of the early jurisprudence of both the Commission and the European

\footnotetext{
74 Beghal SC (n 57), [125].

75 Austin HL (n 6), [34].

76 See, for example, Osypenko v Ukraine [2010] ECHR 4634/04, [51]-[65].

77 Austin HL (n 6), [28].

78 Ibid [63].

79 Creanga v Romania [2012] ECHR 29,226/03, (2013) 56 EHRR 11, [93]. Herein Creanga. Creanga was not cited in Austin. We now find ourselves in the unfortunate position of having two Grand Chamber judgments that are, in principle, inconsistent.

${ }^{80}$ Austin HL (n 6), [29].
} 
Court held, indicated the presence of a balancing mechanism in Article 5. Moreover, such balancing could be seen with respect to other rights, where in the case of Article 3 ECHR it was a long-standing and essential feature of the jurisprudence. ${ }^{81}$ Thus a 'pragmatic interpretation' allows a 'fair-balance' to be struck when deciding whether a deprivation of liberty has occurred under Article 5. In other words, in addition to the express limits on the right to liberty set forth in Article 5(1) the article contains a further implied limitation that allows the authorities to further balance the right against unarticulated public interest considerations.

This development should not be surprising. From Dallison v Caffrey on, English courts have been keen to stress that the rights of the individual are to be balanced against society's interest in detecting and prosecuting crime. ${ }^{82}$ Indeed, by the nineteen-eighties the interests of society had become synonymous with those of the police, who were seen by the courts as acting on their behalf. ${ }^{83}$ Unsurprisingly, the consequentialist reasoning of the common law has been carried over to cases involving Convention rights. For instance, the idea of 'a fair balance' has become integral to the general test of proportionality ${ }^{84}$ in a way not found in other comparable jurisdictions. ${ }^{85}$ In fact, as Ashworth correctly observes, English judges have given rein to a broader notion of 'balancing' than the jurisprudence of the ECHR requires. ${ }^{86}$ And there is perhaps no better example of this than the decision of the House of Lords in Austin, ${ }^{87}$ where a consequentialist justification was read into the Convention. However, the text of Article 5 stipulates exactly what consequentialist public policy considerations are acceptable. Crucially, fundamental rights conferred 'without express limitation should not be cut down by reading implicit restrictions into them, so as to bring them into line with the common law. ${ }^{88}$ But in Austin the House of Lords did exactly that.

Subsequently, the European Court agreed with the House of Lords finding no deprivation of liberty. Article 5(1), the Court concluded, 'must be interpreted in a manner which takes into account the specific context in which the techniques are deployed, as well as the responsibilities of the police to fulfill their duties of maintaining order and protecting the public. ${ }^{89}$ Crucially Austin has subtly altered the Guzzardi test for an additional criterion of context has now been added to the list

\footnotetext{
81 Soering v United Kingdom [1989] ECHR 14038/88.

82 Dallison v Caffrey [1965] QB 348, 367; See also the opinion of Lord Diplock Holgate-Mohamed v Duke [1984] 1 AC 437, 445.

${ }^{83}$ [1981] 1 QB 128, 134.

84 Bank Mellat v Her Majesty's Treasury (No 2) [2013] UKSC 39, [2014] 1 AC 700. Lord Sumption [20]. Lord Reed [72]-[74] dissenting, but not on this point. Herein Bank Mellat.

85 See for example $R$ v Oakes [1986] 1 SCR 103; Kentridge (2001, pp 36-38).

86 Ashworth (2002, p 127).

87 Austin HL (n 6), [34]. Similar arguments can be found in the other judgments discussed herein. Roberts SC (n 33), [41], Roberts HC (n 25), [45]; Beghal SC (n 57), [75] In the context of national security the Supreme Court was happy to take the self-denying ordinance even further; See also Austin ECHR (n 30), [87].

88 S v Zuma (CCT5/94) 1995 (2) SA 642, [15], Kentridge AJ citing himself in Attorney-General v Moagi 1982 (2) Botswana LR 124, 184.

89 Austin ECHR (n 30), [60].
} 
of characteristics for determining when there has been a deprivation of liberty: 'the Court is of the view that the requirement to take account of the "type" and "manner of implementation" of the measure in question enables it to have regard to the specific context and circumstances surrounding types of restriction other than the paradigm of confinement in a cell. ${ }^{90}$ People may now be detained outside the scope of Article 5 by referring to the intention of the police officer, and not the effect on the right to liberty. This runs counter to the previous understanding of Article 5 where intention was only a material consideration during the examination of whether the established interference with the right to liberty could be justified. But in by adopting such an interpretation the European Court has created a serious structural flaw in the architecture of Article 5. Article 5 has long been considered as a strong, though qualified, right. Those qualifications are set forth in Article 5(1). The traditional approach to the interpretation of Article 5 has stressed that given the importance of that article in the Convention, the list of exceptions to that Article is an exhaustive one. ${ }^{91}$ Indeed, so important is the right to liberty, that the list of restrictions contained in Article 5(1) are to be strictly interpreted in a manner consistent with the purpose of Article 5. ${ }^{92}$ In other words, liberty can only ever be deprived under one of the justifications listed in Article 5(1). These permissible limitations are, for instance, much narrower than those allowed under Articles 8-11 of the Convention. ${ }^{93}$ However, as a consequence of Austin this orthodox view of Article 5 is now open to question.

Furthermore, this implied limit has implications for police powers for, as the minority in the European Court in Austin argued, it creates a carte blanche for police activity that interferes with the right to liberty, granting in effect a broader range of public interest limitations than the express text of the Article 5 allows. Balancing the right to liberty with public interest factors when deciding if the right applies undermines the effectiveness of the right and confines the guarantee to a limited set of circumstances. At a stroke the courts have created the legal black hole that Murdoch warned of. ${ }^{94}$ Indeed, it was only a matter of time before the scope of the limitation was extended. In Hicks ${ }^{95}$ the Supreme Court relied on the authority of Austin $^{96}$ to justify the use of preventative detention by the Metropolitan Police during the 2011 Royal Wedding. ${ }^{97}$ Hicks, other republicans, and several 'zombie' protestors had all been arrested on in order to prevent an imminent breach of the peace. The police argued the applicants intended to disrupt the Royal Wedding, and on that basis they were arrested and detained in custody until the wedding was over. Lord Toulson concluded that the arrest and detention were lawful under both the inherent

\footnotetext{
90 Austin ECHR (n 30), [59].

91 Saadiv United Kingdom [2008] ECHR 13229/03, [43].

92 Vasilevia v Denmark [2003] ECHR 52792/99, [32]-[33]. Herein Vasilevia.

93 Ciulla v Italy [1989] ECHR 11152/84, [41].

94 Murdoch (1993, p 497).

$95 R$ (Hicks) v Commissioner of the Police of the Metropolis [2017] UKSC 9, [2017] AC 256. Herein Hicks.

96 Austin HL (n 6), [34].

97 Hicks (n 95), [31] Lord Toulson.
} 
proportionality of Article 5 and Article 5(1)(c) itself. ${ }^{98}$ Once more the right to liberty was balanced away in favour of public order. ${ }^{99}$

\section{An Alternative Interpretation of Article 5?}

In an important aspect of Convention interpretation and application the current approach of the courts is open to criticism. This naturally begs the question is an alternative interpretation of Article 5 possible? In determining when Article 5 applies the starting point must be to examine the aim and purpose of the guarantee, in other words the guarantee must be given a purposive interpretation. The purpose of a constitutional guarantee is to be understood in light of the interests that it is designed to protect. This analysis 'is to be undertaken, and the purpose of the right or freedom in question is to be sought by reference to the character and larger objects of the charter itself, to the language chosen to articulate the specific right or freedom, to the historical origins of the concept enshrined, and where applicable, to the meaning and purpose of the other specific rights and freedoms with which it is associated within the text of the charter. ${ }^{100}$ Moreover, it is axiomatic that as the HRA is both a legal guarantee of fundamental rights and a remedial statute, the guarantees must be read and interpreted in a generous manner, without implied limits that illegitimately cut down the scope of the rights. ${ }^{101}$

The right to liberty is, as the European Court frequently notes, a right of fundamental importance to the freedom of the individual in a democratic society. ${ }^{102}$ The right to liberty is a strong safeguard against arbitrary or unjustified arrest and detention. ${ }^{103}$ Any deprivation of physical liberty must therefore be executed strictly in accordance with the law. ${ }^{104}$ The principle of legality demands that any deprivation of liberty not only conforms with the law but also that any deprivation of liberty should be in keeping with the primary purpose of Article 5, namely protecting the individual from arbitrariness. ${ }^{105}$ This requirement is amplified in the rule that all laws interfering with the right to liberty must be sufficiently accessible and precise. The European Court has previously held that such an interpretation is consistent with the aim and purpose of Article 5, namely preventing arbitrary deprivations of liberty. ${ }^{106}$ Thus care must be taken to ensure that the principle of legal certainty is

\footnotetext{
98 Ibid [41] Lord Toulson.

99 Ibid [29]-[30] Lord Toulson; A subsequent application to the European Court was declared inadmissible: Eiseman-Renyard v United Kingdom [2017] ECHR 57,884/17.

100 R v Big M Drug Mart [1985] 1 SCR 295, [117] Dickson J; See also Alexy (2002, pp 84-86, p 180 and $\mathrm{p}$ 199).

101 Minister of Home Affairs (Bermuda) v Fisher [1980] AC 319, 328 Lord Wilberforce.

102 McKay (n 10), [122]; Lukanov v Bulgaria [1997] ECHR 21915/93, [41].

103 Engel (n 11), [58].

104 Cyprus v Turkey (1992) 15 EHRR 509, [119].

105 Amuur v France [1998] ECHR 17/1995, [50].

106 Winterwerp $v$ The Netherlands [1979] ECHR 6301/73, (1980) 2 EHRR 387, [37].
} 
satisfied. ${ }^{107}$ The importance of preventing the abuse of this right is further reflected not only in the requirement that its exceptions are strictly and narrowly interpreted but also in the requirement that interfering powers be exercised in a proportionate manner. ${ }^{108}$ The right to liberty is, as the European Court noted, frequently interfered with in circumstances where legal protections are ineffective, and the rule of law can be easily subverted. ${ }^{109}$

All this, of course, reflects one of the principal considerations of the drafters of the ECHR which was, as the former Commission concluded in the East African Asians Case, the 'protection [of the individual] against arbitrary arrest and detention. ${ }^{110}$ Such concerns were once those of English law. Blackstone, for example, long ago observed that:

the law of England regards, asserts, and preserves the personal liberty of individuals. This personal liberty consists in the power of loco-motion, of changing situation, or removing one's person to whatsoever place one's own inclination may direct; without imprisonment or restraint, unless by due course of law .... [The] confinement of the person, by secretly hurrying him to gaol, where his sufferings are unknown or forgotten is a .... dangerous engine of arbitrary government. ... [Moreover] the confinement of the person, in any way, is an imprisonment. So that the keeping a man against his will in a private house, putting him in the stocks, arresting or forcibly detaining him in the street, is an imprisonment. ${ }^{111}$

Therefore, reading Article 5 as simply applying to classical deprivations of liberty, such as imprisonment and arrest, would thus be to adopt a restrictive interpretation at odds with both the text and the intentions of the framers. Such an interpretation would confine Article 5 to situations where the individual was in jeopardy of imminent arrest, while leaving situations short of that unregulated save in cases of egregious abuse. In fact, there is nothing in the travaux préparatoires to indicate that Article 5 was intended to apply only to classical deprivations of liberty. Article 5 must apply to situations that are not arrests because although an arrest includes detention, detention does not necessarily include an arrest. Detention thus includes an element of state compulsion, which might include but is not limited to arrest, but which nevertheless interferes with the physical liberty and security of the individual.

\footnotetext{
107 Khudoyorov v Russia [2005] 6802/02, [125].

108 Vasileva (n 92), [41].

109 McKay (n 10), [123].

110 [1973] ECHR 4403/70, (1981) 3 EHRR 76, [222].

111 Blackstone, (1765, 1:134-135). The right of locomotion is recognised to be part of the right to liberty and security by the US Supreme Court: Shapiro v Thompson 394 US 618, 629 (1969).
} 


\section{Deprivations of Liberty: A New Test Based on Coercion?}

How then should Article 5 be read when considering the interactions between the citizen and police? The police have a duty to prevent and detect crime. In the pursuit of that duty they interact with the public. Strictly speaking there is no legal duty to cooperate with police requests where they are made without legal authority. ${ }^{112}$ The police may not detain a citizen 'to help with enquiries. ${ }^{113}$ Without statutory authority the police may not detain someone for questioning. ${ }^{114}$ The basis of policing is consent. ${ }^{115}$ Indeed, the Philips Commission began its discussion of the necessity of coercive powers for the conduct of effective investigations from the starting point of consent. Both arrest and stop and search were paradigm examples of coercive powers that involved deprivations of liberty. ${ }^{116}$ Unsurprisingly, section 2(8) of PACE allows an officer to detain an individual for 'such time as it is reasonably required to permit a search to be carried out. ${ }^{117}$ Without the authority of section 2(8) PACE detentions for stops and searches would be unlawful. ${ }^{18}$ There is no common law power to stop and search. ${ }^{119}$ But whatever the theory of policing a citizen normally complies with requests from police officers, driven by a mixture of respect for authority, a desire to help, fear and ignorance as to the extent of police powers. Members of ethnic minorities may in fact feel less able to walk away from such requests or encounters. The over policing of racial minorities, long documented, has arguably created a situation where individuals who are exposed to frequent and formal interactions with the police more readily comply with demands in order simply to escape. ${ }^{120}$ Often, such encounters are not just frequent but also unpleasant. ${ }^{121}$

However, with respect to the power of stop and search the situation is more formal. While in theory a person who is stopped and asked to account could simply walk away a refusal to submit to a stop and search constitutes a criminal offence, as does wilfully obstructing such a search. ${ }^{122}$ Both offences are punishable by imprisonment. Of course, it is most unlikely that the average citizen is aware of their exact legal position and is likely when faced with a demand from a police officer to comply rather than risk assault or arrest for obstruction. As Robert Goff LJ observed, a police officer has the 'advantage of authority.' ${ }^{123}$ An officer does not need to bark orders. Police officers are perceived as an authority with whom compliance is

\footnotetext{
112 Rice v Connolly [1966] 2 QB 414, 419 Parker LCJ.

${ }^{113} R$ v Lemsatef [1977] 2 All ER 835, 839 Lawton LJ; I I v Bulgaria [2005] ECHR 44,082/98, [87].

114 Kenlin v Gardner [1967] 2 QB 510, 519 Winn LJ.

115 Home Office (2012).

116 Phillips (1981, paras 3.2-3.3).

117 Police and Criminal Evidence Act 1984, s 2(8).

118 Roberts SC (n 27), [29].

119 Kenlin (n 114), 519.

${ }^{120} R$ v Le 2019 SCC 34, [109] - [110] Brown J. Herein Le; Strauss (2001, pp 241-244).

121 Young (2017).

122 Criminal Justice and Public Order Act 1994, s 60(8); Police Act 1996, s 89(2); PACE, s 117 and (Home Office, 2015, para 3(2)).

${ }^{123}$ Collins $v$ Wilcock [1984] 1 WLR 1172, 1176.
} 
required. ${ }^{124}$ Indeed, there is evidence that supports the idea that obedience to authority is so 'deeply ingrained, that people will obey authority even when it is not in their own best interest to do so, and that obedience increases when the authority figure has visible trappings of authority, such as a uniform.' ${ }^{125}$ Psychological compulsion in such circumstances can make the restraint of liberty involuntary and thus amount to a deprivation. Indeed, in light of this can we say that when an individual is detained under a coercive power for a stop and search he/she is any longer at liberty?

Moreover, the nature of police encounters is, as the European Court has noted, coercive even when they are brief. ${ }^{126}$ For instance, although the European Court did not express a final view in Gillan, it nevertheless noted that 'this element of coercion is indicative of a deprivation of liberty within the meaning of Article 5(1). ${ }^{127}$ But since then the European Court has developed the concept of coercion with greater clarity, particularly in cases where Article 8 has no application. In Shimovolos v Russia the European Court reiterated its earlier views expressed in Gillan. ${ }^{128}$ In Shimovolos the applicant was stopped by the police. After they had checked his identity papers they escorted him to the police station, under the threat of force if he refused. It was made clear to the applicant that he was not free to leave the station unless he was authorised to do so. At the police station the applicant was detained for forty-five minutes while he was briefly questioned and his details were checked against the police records. Only then was he allowed to leave. The court concluded that 'there was an element of coercion which, notwithstanding the short duration of the arrest [sic], was indicative of a deprivation of liberty within the meaning of Article 5(1). ${ }^{, 129}$

Similar reasoning can be seen in Foka v Turkey. ${ }^{130}$ In Foka it was argued by the respondent that the applicant had not been formally detained by the Turkish police at the border between the two halves of Cyprus. The applicant refused to allow a search of her bags and was placed by the officers in a police car and taken to the police station. At the police station her person and bag were search, some items were confiscated, she was fined and then released to continue her journey. The Turkish government argued that Article 5(1) was not applicable because the applicant's detention was merely transient and temporary. ${ }^{131}$ Foka argued that she had been forcibly restrained and compelled to go to the police station and confined there against her will. ${ }^{132}$ The European Court agreed: 'As force was used in order to compel the applicant to get into the car, the Court considers that there was an element of

\footnotetext{
${ }^{124}$ Nadler (2002, p 189 and pp 201-202).

125 Strauss (2001, p 236) citing work by Stanley Milgram and Leonard Bickman.

126 Shimovolos v Russia [2011] ECHR 30,194/09, [49].

127 Ibid [57].

128 Ibid.

${ }^{129}$ Ibid [50]. The 'arrest' was a de facto one. It fell outside the scope of any of the exceptions to Article 5(1). See further [51]-[57].

${ }^{130}$ Foka v Turkey [2008] ECHR 28940/95. Herein Foka.

131 Ibid [69].

132 Ibid [66].
} 
coercion, which affected not only the applicant's freedom of movement, but also her liberty. ${ }^{133}$

Equally, in Venskute $v$ Lithuania ${ }^{134}$ the European Court examined an application where the individual's will had been overborne by police action. Venskute was suspected of defrauding an insurance company, and consequently a pre-trial investigation was instituted in accordance with Lithuanian law. Two police officers went to the applicant's workplace, a restaurant, where they introduced themselves. According to the applicant the officers threatened to use force if she refused to accompany them. However, the police officers claimed that they merely invited the applicant to accompany them. ${ }^{135}$ Thus in determining whether the Article 5(1) guarantee had been engaged was the question of whether the applicant had gone to the Vilnius police HQ as a consequence of free will or because of mental coercion. ${ }^{136}$ The European Court held that the evidence pointed in the direction of the latter. Furthermore, it was unrealistic to assume that during the applicant's detention in the police HQ she was free to leave during the five and a half hours before she was formally arrested. This detention in the police HQ constituted a de facto deprivation of the applicant's liberty. ${ }^{137}$

Finally, since Shimovolos there have been a number of Russian applications that involved the Federal Code of Administrative Offences. These cases are interesting because like stop and search powers they involve a form of formal control that falls short of arrest in law. The Federal Code authorises 'the competent authorities to compel a person to follow a competent officer. ${ }^{138}$ The Code provides that a person can only be escorted to a police station for the purposes of drawing up a record of an alleged administrative offence if it is not practicable at the place where it occurred: if this not the case or cannot be subsequently demonstrated then any deprivation of liberty caused by a use of the power is unlawful. ${ }^{139}$ In many ways the powers contained in the Federal Code are analogous to those of stop and search. Both are intended to facilitate investigations. Similarly, neither is a formal power of arrest. And they are both exercised by police officers in a manner that leaves no scope for non-compliance. Indeed, non-compliance would undoubtedly lead to formal arrest. Thus, there is an element of control and coercion which, although it might be short lived, is intrusive in nature. In Tsvetkova $v$ Russia ${ }^{140}$ the European Court examined a number of co-joined applications that all involved the use of administrative escorting under the Federal Code. The European Court concluded that the practice of administrative escorting amounted to a deprivation of liberty. In reaching this conclusion

\footnotetext{
133 Ibid [78].

134 [2012] ECHR 10645/08.

135 Ibid [8]-[10].

136 Ibid [73].

137 Ibid [74].

138 Article 27(1)-(2). In addition, under Article 27(3) a person may be subject to a formal arrest. The powers are helpfully summarised in Butkevich v Russia [2018] ECHR 5865/07, [33]-[34].

139 Timishev v Russia [2017] ECHR 47598/08, [22]. Lashmankin v Russia [2017] ECHR 57818/09, [489].

140 [2018] ECHR 54381/08.
} 
the court made no reference to Guzzardi. Instead, the court observed that none of the applicants enjoyed any free will when escorted: 'Throughout the events there was an element of coercion which notwithstanding the relatively short duration of the procedure in certain cases was indicative of a deprivation of liberty with the meaning of Article 5(1), ${ }^{141}$

Coercion can be present even where officers do not rely expressly upon the authority of the law. In Rozhkov v Russia (No.2) ${ }^{142}$ the applicant was visited in his office by the police. The applicant was informed that his name was on a list of suspects and that he was to follow the officers, so he could be interviewed. The applicant was not shown any authority for the request, and unsurprisingly refused: He was not, however, arrested. The officers merely informed the applicant that they would employ force if necessary. At a subsequent visit the applicant was treated in an identical manner. The European Court concluded that on both occasions that the applicant had been deprived of his liberty: 'The Court considers that throughout events on that day there was an element of coercion which notwithstanding the short duration of the procedure was indicative of a deprivation of liberty within the terms of Article 5(1) ECHR.' 143

The recognition of the effect that coercive police powers have on the individual has long been a central feature of the jurisprudence of the Canadian Supreme Court when interpreting section 9 of the Canadian Charter. ${ }^{144}$ Indeed, Canadian law crucially recognises that coercion can go beyond the physical and encompass the psychological. This case law has important lessons for the interpretation and application of Article 5. ${ }^{145}$ Thus, in Therens the Canadian Supreme Court considered what constituted a deprivation of liberty for the purposes of section 9 and thus the point when the guarantees of section 10 of the Charter would come into play. ${ }^{146}$ In Therens the Supreme Court had to determine whether there had been a deprivation of liberty when a car driver was requested to undertake a breathalyser test by a police officer under the Criminal Code. If there had been a deprivation of liberty the defendant would be entitled, it was argued, to the assistance of counsel as required by Sect. 10 of the Charter. In deciding that there had been a deprivation of liberty Le Dain J held that a detention occurred 'when a police officer or other agent of the state assumes control over the movement of a person by a demand or direction which may have significant legal consequences and which prevents or impedes access to counsel. when a police officer or other agent of the state assumes control over the movement of a person by a demand or direction which may have significant

\footnotetext{
141 Ibid [107]-[108].

142 Rozhkov v Russia (No.2) [2017] ECHR 38898/04.

143 Ibid [79].

144 s 9 of the Canadian Charter of Rights and Freedoms (1982) provides: 'Everyone has the right not to be arbitrarily detained or imprisoned.'

145 Canadian jurisprudence has frequently been cited with approval by the European Court. See, for example, the decision of the European Court in Allan v UK [2002] ECHR 48,539/99 where the court expressly refers to the guidance that Canadian jurisprudence provides in assisting with the interpretation of Article 6 ECHR: [30]-[32], [51].

146 Section 10 provides a number of rights, such as the right to counsel, to those arrested or detained.
} 
legal consequences. ${ }^{147}$ The key question is, therefore, when faced with a demand or direction from an agent of the state, does a person reasonably regard himself as free to refuse $?^{148}$ If the powers are backed by the possibility of criminal liability for a refusal to comply then there is in effect compulsion ${ }^{149}$ : 'any criminal liability for failure to comply with a demand or direction of a police office must be sufficient to make compliance involuntary.' ${ }^{150}$ Thus as police action is by its nature intimidating, and the citizen is uncertain as to the extent of police powers, ${ }^{151}$ compliance in such street encounters is not really voluntary. ${ }^{152}$

The concept of coercion was re-considered by the Supreme Court of Canada in Grant. ${ }^{153}$ In Grant the appellant was stopped and asked to account for his presence in a Toronto suburb. Three officers were undertaking surveillance operations in the suburb as a consequence of a series of robberies. The officers' suspicions were aroused by an intense stare that the appellant gave the officers while 'fidgeting' with his coat and trousers in a suspicious way. The Canadian Supreme Court was asked to re-consider what constituted the definition of 'detention' under sections 9-10 of the Charter. At the outset the majority recognised that the definition of 'detention' was imperative to the proper effectiveness of the guarantee. An overbroad definition, that is too generous, would result in every fleeting interference or delay falling within the scope of the guarantee, and would unquestionably impede effective policing. Whereas, read narrowly all but situations where the police take explicit control, via for example arrest, would fall outside the guarantee leaving citizens open to abusive policing. ${ }^{154}$ The latter interpretation was rejected in Therens whereas in the earlier case of Mann the Canadian Supreme Court had rejected an application of the guarantees where the interaction between the police and citizen involved 'no significant physical or psychological restraint.' ${ }^{155}$ Thus there is no detention when the police stop a person for purposes of identification, or even informal questioning. A person might be delayed, but he/she is not detained. The text of section 9 of the Charter indicates that for a detention there should be a significant deprivation of liberty with legal consequences. ${ }^{156}$ Clearly this would not only be the case where an individual is subject to a physical deprivation of his/her liberty, but would also be true where he/she had psychologically been detained. An individual would be psychologically detained where he/she is not only 'legally required to comply with a direction or demand, as in the case of a roadside breath sample ... [but also] where

\footnotetext{
$147 R v$ Therens [1985] 1 SCR 613, [53] dissenting, but not on this point. Herein Therens.

148 Ibid [54].

149 Ibid [56].

150 Ibid [56].

151 This is especially true of s 60 Criminal Justice and Public Order Act 1994 which may be brought into force and even the most legally aware citizen would not know that the police enjoy this power because there is no publication requirement.

152 Dedman $v R$ [1985] 2 SCR 2, [59] Le Dain J.

$153 R v$ Grant [2009] 2 SCR 353. Herein Grant.

154 Ibid [24].

$155 R v$ Mann [2004] 3 SCR 59, [19] Iacobucci J. Herein Mann.

156 Ibid [29].
} 
there is no legal obligation to comply with a restrictive or coercive demand, but a reasonable person in the subject's position would feel so obligated. ${ }^{157}$ At one end of the spectrum psychological detention will merge with arrest or imprisonment and 'a legal obligation to comply with a police demand or direction' will constitute a detention. ${ }^{158}$ In these circumstances it is not realistic to argue that a person is free to comply, when a refusal will lead to arrest and potential prosecution. Nevertheless the Canadian Supreme Court in Grant went on to examine the various situations where a person interacts with the police but there is no restraint or constraint of choice that has legal consequences. Does the Charter apply? In the majority of cases the answer would be 'no'. For instance, helping a police officer with door-todoor enquiries will not ordinarily have legal consequences and thus attract Charter protection. Being asked to assist the police with general enquiries in the street, a moral and social duty, does not normally have legal consequences either. However, the Charter might apply if the enquiries escalated. In circumstances where neither physical restraint nor legal obligations are present the Canadian Supreme Court held that a contextual approach would be necessary in order to determine whether the person had been detained. A court would need to look at the circumstances that gave rise to the encounter, the nature and language of the officers, and the characteristics of the defendant. Crucially as part of that exercise a court would need to objectively examine the particular characteristics of the detainee. In $L e^{159}$ the Supreme Court of Canada held that it would take judicial notice of the evidence of race relations in deciding such cases. In such cases it was, as Brown J noted, important that the court took 'into consideration the larger, historic and social context of race relations between the police and the various racial groups and individuals in our society. ${ }^{160}$ The key question is how would a 'reasonable person of a similar racial background perceive the interaction with the police. ${ }^{161}$ As in the United Kingdom, ${ }^{162}$ Canadian racial minorities have a disproportionate degree of contact with law enforcement agencies. ${ }^{163}$ In $L e$ the accused was young, Asian and small in stature. The police had unlawfully entered the backyard of a townhouse where Le was chatting with friends. The police had no suspicion that Le was involved in any criminal behavior and no authority to act in the manner than they did. A reasonable person sharing these characteristics would in that context be 'profoundly intimidated' by the police and would thus be detained for the purposes of section 9 of the Charter. ${ }^{164}$

\footnotetext{
157 Ibid [30].

158 Ibid [34].

159 Le (n 120), [75].

160 This contrasted with racial profiling where the principal focus would be upon the motivation of the police, ibid [76].

161 Ibid, [75].

162 For example, see Willis (1983) or the Equality and Human Rights Commission (2012).

163 Le (n 120), [90]-[94] which details research undertaken in Canada.

164 This issue was barely considered in by the court in Roberts SC (n 33), [37].
} 


\section{The Consequences of a New Interpretation Based on Coercion}

In the context of police powers short of arrest the traditional test for deprivation outlined in Guzzardi has failed to make Article 5 'practical and effective' but rendered it 'theoretical or illusory.' ${ }^{165}$ However, the kernel of a more suitable approach exists. As was outlined above the European Court has periodically referred to the role of coercion in deciding whether there has been a deprivation of liberty. In the context of police powers the Guzzardi approach should be replaced by reasoning based on the concept of coercion. The nascent concept of coercion in European law should be further developed by drawing upon Canadian precedent.

A reliance coercion would have a number of advantages. First, coercion, both physical and psychological, reaches deprivations of liberty beyond the classic incarnation scenarios such as prison and arrest. As such, a coercion-based interpretation better represents the purpose behind the Article 5 guarantee. It covers the classic deprivations, arrest providing the par excellence example, but crucially captures the psychological control of individuals by the police that would on the Guzzardi approach fall outside Article 5. Of course there is a tension here between a restrictive reading that limits the scope of Article 5 to classic detentions that is when the police take explicit control over the individual and compel obedience, and an overbroad interpretation where detention is read as encompassing even the most fleeting delay such as social interaction. However, the concept of coercion offers a useful middle way between the two extremes. Physical liberty protected by Article 5 is not the preserve of an automaton but of autonomous individuals in a free society. The liberty interests of the individual depend on psychological liberty. Where an individual is subject to coercive powers, such as stop and search powers under PACE, there is a legal obligation to comply. There is no choice. Just as those 'kettled' in Austin had no choice. The element of coercion removes the individual's ability to exercise his/her physical liberty on pain of criminal penalty. Article 5(1) should surely then apply in these circumstances. The argument that the operation of coercive powers is trivial, for example a person is merely 'kept waiting' or that the experience of being stopped and searched was a short-lived one, misses the important context of how these powers are used. Police stops are inherently coercive, both legally and psychologically. ${ }^{166}$ These powers represent a direct gateway to the criminal justice process for powers to stop and search individuals are intended, in part, to discover evidence of criminality. Moreover, setting a high threshold for the engagement of Article 5 effectively removes from scrutiny areas of low-level discretionary powers that have historically been abused, ${ }^{167}$ and licences a power to do what Article 5 is intended to stop. Furthermore, abuses of police power 'will rarely affect respectable members

\footnotetext{
165 Artico v Italy [1980] ECHR 6694/74, [33].

166 All the more so for minority groups for whom they are particularly humiliating, frightening and degrading: Tanovich, (2002, p 163).

167 Sanders and Young (2008, p 289).
} 
of the middle classes,' but will instead 'focus upon the poor and on the marginal, minority groups.' 168

How then would the new interpretative approach to Article 5 affect, for instance, the result of Austin and Roberts? The applicants in Austin were closely detained for several hours and prevented leaving by the imminent threat of arrest. The physical control of the applicants was clearly coercive both physically and psychologically. The question under Article 5 would become 'can this deprivation be justified?' In Austin the applicants should have succeeded for the very simple reason that Article 5(1) does not contemplate a general public order exception. This questionable interpretation of an already carefully qualified Article has seriously weakened the protection of the guarantee and needs to be revisited by the European Court as a matter of urgency. Furthermore, because the claims are dismissed when determining whether there has been a deprivation of liberty important issues such as the legality and proportionality of the police action are never properly scrutinised. If modern public-order policing necessitates a limit on the right to liberty then it is open to the Contracting States to amend Article 5 through an additional protocol. Indeed, on one level the absence of a public order exception in Article 5 is puzzling given the frequent references to public order elsewhere. However, an examination of the travaux préparatoires reveals that the final form and structure of Article 5 was primarily the responsibility of the United Kingdom. ${ }^{169}$ The original drafts of the Convention proposed to guarantee the right to liberty and security in a manner unqualified by a long list of specific exceptions. But during the drafting process, at the instigation of the United Kingdom delegation, the draft was amended to include a list of permissible limitations. The United Kingdom successfully argued that it was possible to define all the reasonably necessary limitations that states require. ${ }^{170}$ Ironically, this has proved not to be the case.

In any case, shortly before its judgment in Austin v United Kingdom the European Court handed down another judgment involving Article 5. In Creanga v Romania the European Court observed that the case law examining the purpose of a detention when deciding if there had been a deprivation of liberty had evolved since the era of the Commission and as such 'the purpose of measures by the authorities depriving applicants of their liberty no longer appears decisive for the Court's assessment of whether there has in fact been a deprivation of liberty. ${ }^{171}$ This welcome clarification of the law was sadly short-lived. Indeed, Austin has proved more influential despite the attempt of the European Court to confine its decision to 'the specific and exceptional facts of this case. ${ }^{172}$ As Roberts illustrates, the temptation to use the tool of definitional balancing is too great for judges seeking to adopt a limited interpretation

\footnotetext{
${ }^{168} R v$ Landry (1986) 25 CCC (3d) 1, 30 La Forest J.

169 Council of Europe (1956, pp 12-13, p 14, and p 16).

${ }^{170}$ Ibid, 17-18. Amendment of 4th February 1950 presented by Sir Oscar Dowson. Council of Europe (1976, pp 186-188).

171 Creanga (n 79), [93].

172 Austin ECHR (n 30), [68].
} 
of the right to liberty. ${ }^{173}$ Crucially, in a context where the state is exercising coercive powers there can be no place for a de minimis principle. Thus, once there has been a deprivation of liberty the shortness of that deprivation will not affect that finding. In other words, once subject to a coercive power and thereby deprived of their liberty the fact that the stop and search will only last a few minutes will not affect the finding of a prima facie infringement of Article 5 that needs to be justified. ${ }^{174}$

Once it is established that a stop and search power constitutes a deprivation of liberty it would then fall to be decided whether that interference could be upheld as an exception within the terms of the express exceptions set out in Article 5(1) 175 or now as part of a general public interest balance in line with the opinions in Aus$\operatorname{tin}^{176} \mathrm{With}$ respect to the latter the sorts of items, knives and other deadly weapons, that justify the use of section 60 CJPO pose a threat to life, and could therefore fall within the scope of Austin. However, at this juncture two important points must be made. First, the need to ensure a fair balance through a reconciliation of the state's positive obligations to safeguard life under Article 2 and the right to liberty under Article 5 was developed without reference to long standing authority, which counsels caution here. ${ }^{177}$ The European Court has yet to reconcile this jurisprudence in a coherent manner. ${ }^{178}$ And second, as argued above, Austin is a novel and dangerous departure from the accepted principles of Convention and constitutional interpretation, which ought not to be followed.

Be that as it may, with respect to the express limitations contained in Article 5, without doubt Article 5(1)(b) would be the most appropriate. Article 5(1)(b) justifies 'the lawful arrest or detention of a person for non-compliance with the lawful order of a court or in order to secure the fulfillment of any obligation prescribed by law. ${ }^{179}$ This will, of course, require an assessment of the proportionality of the impugned provision. Yet the approach of the English courts is once more open to question. For instance, in Beghal the majority were content to dismiss the application of Article 5 on the basis that in the case before them there had been a justified interference with the right. However, as Lord Kerr observed in his dissent, the disproportionality of the interference was created by the power itself, rather than a specific exercise of it. Importantly, as was noted above, Lord Kerr reached this conclusion after applying

\footnotetext{
173 Roberts $H C$ (n 25), [41].

${ }^{174}$ Brega v Moldova [2012] ECHR 61485/08. Here the applicant was bundled into a trolley bus by several plain-clothes detectives in order to keep him from reaching a demonstration. The restraint lasted for eight minutes. The European Court held that this de facto detention amounted to a deprivation of liberty.

${ }^{175}$ Engel (n 11), as the court noted at [57] 'the list of deprivations of liberty set out therein is exhaustive, as is shown by the words "save in the following cases".'

${ }^{176}$ Austin HL, (n 6), [34] Lord Hope. In Hicks SC (n 95) Lord Toulson considered the arrest of the appellants under both the Austin doctrine and Article 5(1)(c) approach before determining that their preventative detention was justified under the latter.

177 See Osman v United Kingdom [1998] ECHR 87/1997/871/1083, [116].

178 The European Court mentioned the duties under Articles 2 and 3 ECHR in passing during $S, V$ and $A$ $v$ Denmark [2018] ECHR 35553/12, [124] but did not develop any coherent analysis of the tension.

179 Vasileva (n 92), [36] and [38]; Sarigiannis v Italy [2011] ECHR 14569/05, [42]-[44]; and the admissibility decision in Novotka $v$ Slovakia [2003] ECHR 47244/99.
} 
the proportionality test set down in Bank Mellat, ${ }^{180}$ in contrast to the majority who did not. But the lack of rigour at the limitation stage should not be a surprise. Where a court determines a Convention right 'barely' applies any subsequently proportionality analysis will be less than rigorous, and any interference will be more readily upheld without exacting scrutiny. Similarly, the conclusion that an interference is necessary in a democratic society will be more easily met when the application of a right is weak. Unsurprisingly, the courts readily held that the challenges of modern policing provide a strong public interest justification for stop and search powers for example. Yet the need to protect lives and detect crime does not grant the state a carte blanche. Simply because a power is of alleged utility it does not automatically become legal. ${ }^{181}$ In fact, there growing evidence that in this context the claim of necessity is overstated for there is growing evidence that stop and search powers fail to have the deterrent quality that it is often claimed that they enjoy ${ }^{182}$ : Indeed, it seems likely that stop and search has never been particularly effective in controlling crime.' ${ }^{183}$ The evidence shows that a surge in the use of section 60 had little impact on the underlying trend in non-domestic violence. ${ }^{184}$

\section{Conclusion}

It is a remarkable feature of current human rights jurisprudence that Article 5 fails to offer any effective control of coercive police powers. From Gillan through Austin to Roberts Article 5 has consistently been interpreted by the courts in a way that puts police powers beyond Convention control leaving only formal arrest and detention to fall within its provenance. In short, the jurisprudence has failed to keep pace with the expansion of police powers. Only the intervention of the European Court in Gillan and later Beghal has brought much relief, albeit under Article 8 ECHR. Without doubt this is a consequence of the nebulous test in Guzzardi. Yet as the European Court has indicted in several cases another factor is often in play in such cases, namely coercion. Indeed, the concept of coercion provides a more realistic and effective concept to control police powers under Article 5. Here the Canadian experience of employing coercion under the Charter of Rights and Freedoms provides valuable lessons for us. Of course, if we recognize that many powers short of arrest are inherently coercive and that their use involves a deprivation of liberty under Article 5 it will be necessary to subject them to proper scrutiny to determine if the deprivation is justified. But such analysis is necessary if we are to close the legal grey hole in the important area of police powers which has developed as a consequence.

\footnotetext{
${ }^{180}$ Bank Mellat (n 84).

${ }^{181}$ Beghal SC (n 57), [93] Lord Kerr dissenting.

182 Tiratelli (2018).

183 Ibid, p 1226.

184 Ibid, p 1215 and p 1225.
} 
Acknowledgements My thanks to John Edwards, Anne Barlow, Howard Davis, Andrea Lista, Adam McCann, Mike Schmitt, and the anonymous referee for their helpful comments on earlier drafts. The usual disclaimer applies.

\section{Compliance with ethical standards}

Conflict of interest The authors declare that they have no conflict of interest.

Open Access This article is licensed under a Creative Commons Attribution 4.0 International License, which permits use, sharing, adaptation, distribution and reproduction in any medium or format, as long as you give appropriate credit to the original author(s) and the source, provide a link to the Creative Commons licence, and indicate if changes were made. The images or other third party material in this article are included in the article's Creative Commons licence, unless indicated otherwise in a credit line to the material. If material is not included in the article's Creative Commons licence and your intended use is not permitted by statutory regulation or exceeds the permitted use, you will need to obtain permission directly from the copyright holder. To view a copy of this licence, visit http://creativecommons.org/licen ses/by/4.0/.

\section{References}

Alexy, Robert. 2002. A Theory of Constitutional Rights. Oxford: Oxford University Press.

Ashworth, Andrew. 2002. Human Rights, Serious Crime and Criminal Procedure. London: Sweet \& Maxwell.

Blackstone, Sir William. 1765. Commentaries on the Laws of England. Dinton: Clarendon.

Chaskalson, Marcus. 2006. Constitutional Law of South Africa. Cape Town: Juta.

Council of Europe. 1956. 'Preparatory Work on Article 5' (1956) CDH (67), 12. https://www.echr.coe. int/Library/DIGDOC/Travaux/ECHRTravaux-ART5-DH(56)10-EN1674958.pdf. Accessed 18 May 2020.

Council of Europe. 1976. Collected Edition of the "Travaux préparatoires" of the European Convention on Human Rights Vol 3 Committee of Experts. Martinus Nijhoff.

Donohue, Laura. 2007. Counter-terrorist Law and Emergency Powers in the United Kingdom. Glasgow: Irish Academic Press Ltd.

Dyzenhaus, David. 2006. The Constitution of Law. Cambridge: Cambridge University Press.

Equality and Human Rights Commission. 2012. Stop and Think. https://www.equalityhumanrights.com/ en/race-britain/stop-and-think. Accessed 1 June 2020.

Goldstein, Joseph. 1959-1960. Police discretion not to invoke the criminal process. Yale LJ 69: 543-594.

Home Office. 2012. Definition of Policing by Consent. Available from: https://www.gov.uk/government/ publications/policing-by-consent/definition-of-policing-by-consent. Accessed 1 June 2020.

Home Office. 2015. Police and Criminal Evidence Act 1984, Code A. Revised Code of Practice. The Stationery Office. Available from https://assets.publishing.service.gov.uk/government/uploads/syste m/uploads/attachment_data/file/414195/2015_Code_A_web-19-03-15.pdf. Accessed 16 Oct 2019.

Home Office. 2019. Police powers and procedures, England and Wales, year ending 31 March 2019. The Stationery Office. Available from https://assets.publishing.service.gov.uk/government/uploads/syste m/uploads/attachment_data/file/841408/police-powers-procedures-mar19-hosb2519.pdf. Accessed 3 May 2020.

Ip, John. 2017. The legality of 'suspicionless' stop and search powers under the European Convention on Human Rights. Human Rights Law Review 17(3): 523-544. https://doi.org/10.1093/hrlr/ngw025.

Kentridge, Sir Sydney. 2001. Human Rights: A Sense of Proportion. The Tanner Lectures on Human Values. https://tannerlectures.utah.edu/_documents/a-to-z/k/Kentridge_02.pdf. Accessed 1 June 2020.

Lennon, Genevieve. 2016. Searching for Change: Scottish stop and search powers. Edinburgh Law Review 20(2): 178-203.

Murdoch, Jim. 1993. Safeguarding the Liberty of the Person: Recent strasbourg jurisprudence. International and Comparative Law Quarterly 42(3): 494-522. https://doi.org/10.1093/iclqaj/42.3.494. 
Murray, Kath. 2018. The modern making of stop and search: The rise of preventive sensibilities in postwar Britain. The British Journal of Criminology 58(3): 588-605. https://doi.org/10.1093/bjc/azx03 0 .

Nadler, Janice. 2002. No need to shout: bus sweeps and the psychology of coercion. Supreme Court Review 2002(1): 153-222.

Philips, Sir Cyril. 1981. Royal Commission on Criminal Procedure. London: The Stationery Office.

Sanders, Andrew, and Richard Young. 2008. 'Police Powers' in Tim Newburn, Handbook of Policing, 287. Milton: Willan Publishing.

Schabas, William. 2015. The ECHR: A Commentary. Oxford: Oxford University Press.

Steyn, Lord. 2004. Guantanamo Bay-The legal black hole. ICLQ 53(1): 1-15. https://doi.org/10.1093/ iclq/53.1.1.

Strauss, Marcy. 2001. Reconstructing consent. The Journal of Criminal Law and Criminology 92(1): 211-272.

Tanovich, David. 2002. Using the charter to stop racial profiling. Osgoode Hall LJ 40(2): 145-187.

Tiratelli, Matteo, Paul Quinton, and Ben Bradford. 2018. Does stop and search deter crime? Evidence from ten years of London-wide data. The British Journal of Criminology 28(5): 1212-1231. https:// doi.org/10.1093/bjc/azx085.

van Dijk, Pieter. 2006. Theory and Practice of the European Convention on Human Rights, 4th ed. Cambridge: Intersentia.

Waddington, Peter. 1987. Towards Paramilitarism: Dilemmas in policing civil disorder. The British Journal of Criminology 27(1): 37-46. https://doi.org/10.1093/oxfordjournals.bjc.a047650.

Walker, Clive. 2011. Cosmopolitan liberty in the age of terrorism. In International and Comparative Criminal Justice and Urban Governance Convergence and Divergence in Global, National and Local Settings, ed. Adam Crawford, 413-438. Cambridge: Cambridge University Press.

Willis, Carol. 1981. The Use, Effectiveness and Impact of Police Stop and Search Power RPUP 15. London: Home Office.

Young, Richard. 2017. The rise and fall of 'stop and account': lessons for police accountability. In Accountability of Policing, ed. S. Lister and M. Rowe, 18-49. Abingdon: Routledge.

Publisher's Note Springer Nature remains neutral with regard to jurisdictional claims in published maps and institutional affiliations. 